Article

\title{
Livelihood Dependency on Non-Timber Forest Products: Implications for REDD+
}

\author{
Khaing Thandar Soe ${ }^{1}$ and Youn Yeo-Chang $1,2, * \mathbb{D}$ \\ 1 Department of Forest Sciences, College of Agriculture and Life Sciences, Seoul National University, \\ 1 Gwanakro, Gwanakgu, Seoul 08826, Korea; khaingthandasoe@gmail.com \\ 2 Department of Forest Sciences and Research Institute of Agriculture and Life Sciences, \\ Seoul National University, Seoul 08826, Korea \\ * Correspondence: youn@snu.ac.kr; Tel.: +82-02-880-4754
}

Received: 25 March 2019; Accepted: 10 May 2019; Published: 16 May 2019

\begin{abstract}
Deforestation and forest degradation are occurring continuously and posing serious threats to forests and people worldwide. In Myanmar, poor regulation and unsustainable extraction of non-timber forest products (NTFPs) is affecting millions of hectares of natural forests; overexploitation of forest resources is one of the main drivers of forest degradation. Although evidence shows that the extraction of NTFPs results in forest degradation, there have been few studies on what drives rural people to depend on NTFPs and how to address these drivers in terms of policies and measures. Policies and measures are nationally enacted policies and actions that countries undertake to address the causes of deforestation and forest degradation. This study identifies which factors determine the dependence on NTFPs in forest-dependent communities. From these factors, we derived policy implications for the main causes of overexploitation of NTFPs to provide suggestions for developing policies and measures in the design of national Reducing Emissions from Deforestation and Forest Degradation (REDD+) strategies. Focusing on the Taungoo District as a case of dependence on NTFPs by local communities, we conducted a qualitative and quantitative data collection procedure based on interviewing households in the local communities. NTFPs contributed the most to total household income and the main types of NTFPs exploited were charcoal making and bamboo selling. Households with lower education level, less agricultural land, less income from off-farm activities, lived under the poverty line or used only charcoal were more dependent on NTFPs in the study areas. Poverty and fuelwood usage were factors affecting NTFPs dependence for landowners while rice insufficiency, off-farm income and fuelwood usage most affected the NTFPs dependence for landless people. The results suggested that national strategies for REDD+ should take into account local features such as income opportunities and land tenure in order to make local people cooperate with the government to avoid deforestation and forest degradation.
\end{abstract}

Keywords: non-timber forest products; livelihood dependency; REDD+; policy; Myanmar

\section{Introduction}

\subsection{Research Background}

Deforestation and forest degradation are serious threats to sustainable development; their exponential rate of growth poses a severe risk to the world's ecosystems. Forests are common property resources in many parts of the world. As Hardin [1] argues, forests, if open to all for access without restriction, can be overexploited and degraded. Many non-timber forest products (NTFPs) productions operate in open or semi-open access systems of resource tenure, resulting in exploitation of NTFPs [2]. For the sustainability in NTFPs harvest, land and resource tenure are crucial [3]; rapid market expansion 
of products with little or no tenure security leads to over-harvesting [4]. Nevertheless, the institutional innovation, policies, and law enforcement at the local and international levels could help reduce the tragedy of commons [5] and lead to the sustainable utilization of common resources.

Forest degradation critically affects millions of people who depend, directly/indirectly or fully/partially, on forest goods and services at the local, regional, and global levels [6]. This phenomenon is a direct threat to the livelihood of forest-dependent communities as it reduces forest productivity. Degradation often happens due to the complex interaction between direct drivers operating at the local or regional levels and indirect drivers operating at the local, regional, national, and international levels [7]. In terms of general causes, degradation is primarily due to human action in developing countries, while natural events are usually the cause in developed countries [6]. Fuelwood collection, charcoal making, and timber logging are the most severe problems fostering forest degradation in Africa and subtropical Asia, while timber logging and uncontrolled fires are the main drivers of degradation in Latin America [8,9]. Kissinger et al. [10] reported that the primary direct drivers of forest degradation in Myanmar are illegal logging, overexploitation of forest resources, fuelwood collection, and shifting cultivation. Overall, the common perception is that forest degradation in Myanmar is due to anthropogenic activities, specifically the overexploitation of forest resources. However, little is known about the reasons behind these activities driving forest degradation. It is thus important to understand how much people depend on forest resources such as NTFPs and to identify the underlying factors affecting this dependence.

Reducing Emissions from Deforestation and Forest Degradation (REDD+) is an international voluntary mechanism under the United Nations Framework Convention on Climate Change (UNFCCC) designed to mitigate climate change by reducing greenhouse gases (GHG) emissions [11]. Since addressing the drivers of deforestation and forest degradation taking into account both social and natural systems are at the core of the REDD+ mechanism, understanding the underlying mechanisms behind the drivers of forest degradation is imperative to achieve the goals of REDD+. In Myanmar, overexploitation of forest resources resulting from the high dependence of the communities on these materials is one of the main causes of forest degradation. Thus, investigating the underlying causes of the dependence on NTFPs would help design and/or reform policies to address the problems under REDD+.

Another aspect of our research on NTFP dependence by forest-dependent communities in Myanmar is the potential for developing policies and measures (PAMs) that could be used to reduce forest degradation and restore or otherwise improve forest management. PAMs are nationally enacted policies and actions that countries undertake to address the causes of deforestation and forest degradation [12,13]. The combination of PAMs from different sources are required to collectively address priority direct drivers and barriers to implementation, in a coherent way [14]. Depending on the country context (i.e., priority, political preference, capacity, and stakeholders involved), PAMs may be a mixture of legal and institutional reforms, regulatory measures, and incentives taking social and environmental safeguards into account as well as capacity building [15]. The Myanmar National REDD+ Strategy specifies the PAMs to address the priority drivers of deforestation and forest degradation and to overcome the barriers to the sustainable management of forests [16]. Some PAMs such as legal or regulatory reform need to be implemented at the national level while some need to be implemented at the local level [14]. Currently, Myanmar is at the finalizing stage of its National Strategy. So, while some PAMs such as land tenure security and the recognition of customary rights are still in development, others are already being implemented, including the distribution of efficient cooking stoves, development of fuelwood plantations, raising environmental awareness in the local communities, and capacity building of government and non-governmental organizations (NGOs) staffs. The challenges to address the causes of forest degradation are in the implementation stage of PAMs due to the limited information on the underlying causes of forest degradation and the complex links between forests and the local communities. One study also conducted in Myanmar [17] reported that REDD+ intervention did not have a significant impact on the livelihood of the local communities except for contributing to an increase in environmental awareness. This situation highlights the need 
to further explore the underlying causes of deforestation and forest degradation and the dependence of local communities on forest resources when the REDD+ plan is implemented in a specific region. We postulate that to reduce overexploitation of NTFPs, a policy agenda could be developed based on a close examination of the factors that influence local community dependence on NTFPs.

\subsection{Literature Review}

In this study, we used the definition of NTFPs [18], which is compatible with the features of NTFPs in Myanmar. Thus, NTFPs are products that encompass "all biological materials other than timber which are extracted from forests for human use" [18]. The NTFPs used by local communities include firewood, charcoal, poles, thatching grass, bamboo, rattan, resins, ornamental plants, wildlife (products and live animals), fibers, animal fodder, fruits, mushrooms, and other food and medicinal plants [18,19].

The contributions of forest ecosystem services to the livelihood of the local communities have been highlighted by several studies [19-25]. In most developing countries, forest provisioning services are especially important in terms of providing direct benefits to the local communities and, thus, represent a major part of the total economic value of their livelihoods [26]. In addition to their role as a resource for house construction, NTFPs are also used to generate biomass and energy, as well as they provide basic needs such as food, clothing, and shelter. At first, the value of forests was recognized primarily in terms of timber production at the national level. Later on, NTFPs became significant not only at the local level but also at the national level. There is growing evidence that NTFPs contribute significantly to rural livelihoods in developing countries, but are frequently underrepresented at the national level in terms of economic reporting because they are often part of the informal economy [18,27-30]. Literature on the factors influencing forest dependence indicated that off-farm employment opportunities, agricultural income, and access to markets have a negative relationship with forest dependence [31,32].

The literature on the interaction between forests and people has focused on the contribution of forest resources to the livelihood of rural people. Several studies reported the benefits of NTFPs to the livelihood of local communities $[18,19,27-30,32]$. Some others argued that the commercialization of NTFPs adds to the value of forest products by helping the conservation and development of local communities while contributing to the regulation of forest services such as carbon sequestration, hydrological regulation, and biodiversity conservation [33,34]. However, several works also confirmed the negative effects of overexploitation and unsustainable extraction [35-39]. The disadvantages included altered regeneration, species composition [37,38], and change in population structure and density of NTFP species, floristic diversity $[37,39,40]$, and forest degradation $[35,36]$. These studies supported the notion that the higher the dependence on NTFPs, the higher the forest degradation. This is consistent with the current state of forest degradation in Myanmar arising from the overexploitation of NTFPs.

To address the drivers of deforestation and forest degradation, the developing countries participating in the UN-REDD program (United Nations Collaborative Programme on Reducing Emissions from Deforestation and Forest Degradation) are encouraged to develop and implement PAMs to support climate change mitigation and adaptation actions. Similar to other participant countries, government bodies in Myanmar formulate PAMs as part of a national strategy and implement them to meet the country's mitigation targets. Studies on developing REDD+ PAMs are relatively limited and this analysis is further complicated by the fact that the development and selection of appropriate PAMs depends on region-specific deforestation and forest degradation drivers, national circumstances, and the purposes of the national REDD+ strategy. Scriven [41] provided contextual data and information to aid the development of PAMs targeted to the Peruvian Amazon and reported that care must be taken to build and structure practical PAMs in the local context. As only a few countries have submitted their national REDD+ strategy to the UNFCCC REDD+ platform, their strategies, approaches and national programs are the only illustrations of PAM development available. 


\subsection{Rationale for the Study}

A little more than a third of Myanmar's land area consists of forest land-29 million hectares out of a total land area of 65.8 million hectares [42]. Myanmar ranked third in annual net loss of forest area during 2010-2015 [43] and the area of its degraded forests continues to increase at a rate of $0.29 \%$ annually, which is much higher than the global average of $0.13 \%$ [44]. The estimated indigenous population is approximately 14-19 million and most of the population live in or around forest areas [45] and depend on forest resources for the collection of NTFPs for sustenance and for generating income [45]. The rural population is approximately $70 \%$ of the total population [46] and the extraction of NTFPs occurs in most of the protected areas (PAs) of the country. As a consequence, PAs in Myanmar are threatened by grazing, hunting, fuelwood extraction, and permanent settlement of rural communities [47].

Both the 1992 Forest Law and the 2016 Community Forestry Instructions (CFI) stipulate that local communities have a right to extract a stipulated quantity of forest products for subsistence use, but permission is needed if extraction activities take place on a commercial scale $[48,49]$. However, common resources are vulnerable to powerful interests due to inadequate PAMs for the conservation of forests. In particular, inefficient monitoring on the utilization of forest resources and inadequate implementation of conservation programs are the limitations to address over-exploitation of forest resources, illegal logging or illegal charcoal making and related activities. Thus, addressing these drivers needs a new management regime considering PAM options.

Poor regulation and unsustainable extraction of NTFPs are affecting millions of hectares of natural forest in Myanmar. According to the Taungoo District 10-year forest management plan [50], the demand for bamboo in Oaktwin township in 2015-2016 was 3.45\% higher than the estimated production from reserved forests while the production in Yaetarshae township could meet the estimated demand in the township. In the case of firewood and charcoal, the production of forests could not fulfill the demand in both townships. A few studies have been conducted in different areas of Myanmar attempting to explain the determinants of forest income, economic contribution of NTFPs to the rural livelihood, and the relationship between basic needs and forest products [17,51-53]. Win et.al [54] studied the consumption rates and patterns of firewood and charcoal in Yaetarshae township. They reported that as the demand for firewood and charcoal is increasing, increased production of firewood and charcoal could threaten further forest degradation in that area.

As overexploitation and unsustainable extraction of NTFPs lead to forest degradation $[35,36]$ and the tendency of further forest degradation in Myanmar, our research seeks to answer the question concerning the factors that determine community dependence on NTFPs. Answering this question provides a number of policy implications that can aid in the development of PAMs as part of a national REDD+ strategy at a local scale.

\section{Materials and Methods}

\subsection{Case Study Description and Data Collection}

The study area, Taungoo District, is located in the northeastern part of the Bago Region in Myanmar between $18^{\circ} 8^{\prime}$ and $19^{\circ} 20^{\prime} \mathrm{N}$ and $95^{\circ} 50^{\prime}$ and $96^{\circ} 45^{\prime} \mathrm{E}$ (see Figure 1). It is connected to Bago Yoma (Yoma means mountain ranges) in the west, with the Kayin mountain ranges in the east and plains from north to south [50]. With a population of approximately one million, almost $80 \%$ of the people in the region live in rural areas [50]. The mean annual precipitation is between 1400- 2400 mm and the average temperature is $27.18^{\circ} \mathrm{C}$ [50]. This district is along the Bago mountain range (Bago Yoma), also known as the home of the Myanmar Teak (Techona grandis). At present, more than $80 \%$ of the forest in the region is degraded [55]. The Taungoo District was chosen for the case study because of this high percentage of degraded forest area, high rural population, and also due to the fact that it is one of the main target areas for REDD+ implementation. 
We designed our research to gather both secondary and primary data. The secondary data concern forest cover, geographical information, demographic data, and area maps were collected from township and district forest departments and the Forest Department at the Ministry of Natural Resources and Environmental Conservation (MONREC). Two townships-Yaetarshae, located within the lower mountainous areas (LMA), and Oaktwin, located within the higher mountainous areas (HMA) - were selected as sampling areas for the field survey. Yaetarshae township occupies an area of $2619 \mathrm{~km}^{2}$ while Oaktwin township has $1385 \mathrm{~km}^{2}$. The rural population in both areas were around 190 thousand (44,000 households) in LMA and 145 thousand (34,000 households) in HMA according to the 2015 census [50]. The surveyed villages were located within low mountain ranges (ranging in elevation from 251-500 m) and high mountain ranges (ranging in elevation from 501-750 m) [56]. Qualitative and quantitative data collection was conducted in October and November 2016 through interviews with key informants, focus group discussions, and face-to-face individual interviews with local residents. Five key informant interviews with government officials (senior officers, foresters) of forest departments at township and district levels were conducted at Yaetarshae and Oaktwin townships and Taungoo District. Interviews with key informants were conducted to understand the geographical conditions of the study areas, forest cover, forest resources extraction and the general livelihood conditions of communities. Moreover, four focus group discussions which included 5-7 village leaders and elders at four village tracts covering 18 villages were organized to understand the general conditions of the villages, livelihood of the communities, forest resource use, and the main types of NTFPs extracted from the surrounding forests. Households were randomly selected from a total of 77,863 rural households and face-to-face interviews were performed using semi-structured questionnaires. Ultimately, 330 sampled households with valid answers were selected for analysis.

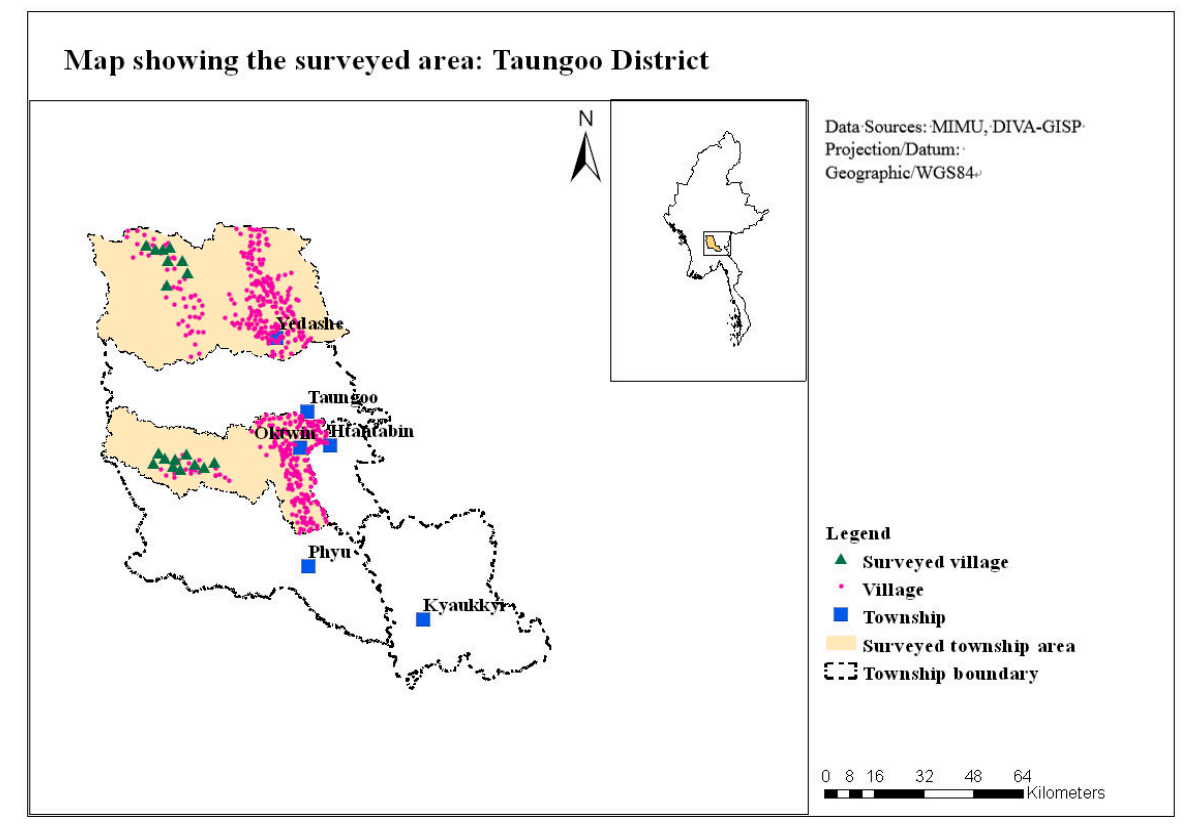

Figure 1. Study area: Taungoo District in the Bago Region, Myanmar. Note: Map created, February 2018. MIMU: Myanmar Information Management Unit; DIVA-GISP: DIVA geographic information system data portal.

\subsection{Variable Descriptions}

The field survey was conducted to collect socio-economic and demographic information about forest-dependent households and their use of NTFPs.

NTFP dependence. The dependent variable measuring NTFP dependence is defined as the relative share of income from NTFPs in total household income, following the definition of forest dependency in $[30,32]$, and is denoted as DEPEND. The definitions of the explanatory variables are given in Table 1. 
Table 1. Description of the explanatory variables.

\begin{tabular}{|c|c|c|c|c|}
\hline Variable & Description & Unit & $\begin{array}{l}\text { Hypothesized } \\
\text { Effect }\end{array}$ & Literatures \\
\hline AGE & Household head age & Years & Positive & $\begin{array}{l}\text { Older rural people are assumed to have greater knowledge of the utilization and extraction of } \\
\text { NTFPs than younger ones and their dependence would therefore be higher }[29,57] \text {. }\end{array}$ \\
\hline SEX & Household head sex & $\begin{array}{c}\text { Male }=1 \\
\text { Female }=0\end{array}$ & Positive & $\begin{array}{l}\text { Men appeared to be more likely to engage in high-return NTFPs extraction activities than } \\
\text { female-headed households }[30,53,58] \text { while some argued that women are more dependent on } \\
\text { subsistence forest income }[59] \text { and their involvement in NTFPs collection is more noteable than } \\
\text { men [60-63]. However, some studies pointed out that sex of household head is no longer } \\
\text { significant to forest dependence }[57,64] \text {. }\end{array}$ \\
\hline EDU & $\begin{array}{l}\text { Household head } \\
\text { completed schooling } \\
\text { years }\end{array}$ & Years & Negative & Education level is expected to have a negative effect $[30,52,57,59]$. \\
\hline HHSIZE & $\begin{array}{l}\text { Number of family } \\
\text { members }\end{array}$ & Persons & Positive & $\begin{array}{l}\text { The more labor available, the more participation in labor intensive NTFP extraction activities } \\
\text { should be reported, thus implying more dependence on NTFPs }[51,64,65] \text {. }\end{array}$ \\
\hline LANDAC & Size of owned land & Acres & Negative & $\begin{array}{l}\text { In general, greater land ownership and level of food-sufficiency characterize wealthier } \\
\text { households in Myanmar's rural communities. The size of owned land has a negative effect on } \\
\text { NTFP dependence [53]. }\end{array}$ \\
\hline RICINSUF & $\begin{array}{l}\text { Number of rice } \\
\text { insufficiency months } \\
\text { in a year }\end{array}$ & Months & Positive & $\begin{array}{l}\text { The number of rice insufficient months within a year } \\
\text { was hypothesized to have a positive effect on NTFP dependence [30,64]. }\end{array}$ \\
\hline OFFINCOM & $\begin{array}{l}\text { Income from off-farm } \\
\text { employment }\end{array}$ & US\$/year & Negative & $\begin{array}{l}\text { Households lacking other employment opportunities appear to be more dependence on } \\
\text { NTFPs [64]. }\end{array}$ \\
\hline POV & $\begin{array}{l}\text { Regional poverty } \\
\text { level a }^{\text {a }}\end{array}$ & $\begin{array}{c}\text { Poverty }=1 \\
\text { Non-poverty }=0\end{array}$ & Positive & $\begin{array}{l}\text { As forest products help as safety nets, support of current consumption, and as a pathway out of } \\
\text { poverty [3,32,66], people under the poverty line depend more on NTFP extraction [22,32]. }\end{array}$ \\
\hline RESIDE & $\begin{array}{l}\text { Residency in high and } \\
\text { low mountainous } \\
\text { areas (HMA, LMA) }\end{array}$ & $\begin{array}{l}\mathrm{HMA}=1 \\
\mathrm{LMA}=0\end{array}$ & Positive & $\begin{array}{l}\text { Remote areas may have fewer income opportunities and higher dependency on forest resources } \\
\text { than those areas with better infrastructure. }\end{array}$ \\
\hline $\begin{array}{l}\text { CCUSE } \\
\text { FWUSE } \\
\text { BOTHUSE }\end{array}$ & $\begin{array}{l}\text { Utilization of wood } \\
\text { fuel }\end{array}$ & $\begin{array}{l}\text { Charcoal user }=1 \\
\text { Firewood user }=2 \\
\text { User of both fuels }=3\end{array}$ & $\begin{array}{l}\text { Positive } \\
\text { Negative } \\
\text { Positive }\end{array}$ & $\begin{array}{l}\text { Fuelwood usage by local people may have an effect on NTFP dependence. The annual household } \\
\text { income for charcoal users was significantly higher on average than for firewood users [67]. }\end{array}$ \\
\hline
\end{tabular}

a (based on 387,785 Myanmar Kyats, MMK/year = \$308/year, as of November, 2016) [68]. NTFPs: non-timber forest products; Variable refers to the independent (explanatory variables) on which the dependent variable (relative share of income from NTFPs in total household income) depends. Description refers to the explanation of the abbreviations of the independent variables. Unit refers to the measuring unit for continuous variables and the denotation of categorical variables. Hypothesized effect on dependent variable refers to the estimated effect of each explanatory variable on the dependent variable. 
Hypothesis on the effect of socio-economic and demographic characteristics on NTFP dependence. The variables postulated to influence NTFP dependence include socio-economic and demographic characteristics. The effect of each explanatory variable on the dependent variable was hypothesized based on previous studies (see Table 1).

\subsection{Methods}

Income accounting. We define household annual income as the sum of the cash income generated from different activities (e.g., crop cultivation, livestock raising, collecting NTFPs, income from migrant family workers, casual labor, and small scale businesses) and the monetary income equivalent to the value of the output of those activities (non-cash income) [66]. Income accounting for the annual income of forest-dependent households was calculated as follows:

Household annual income $=($ NTFP income + migration income + casual labor income + crop cultivation income + livestock income + other income)

$$
Y_{\text {tincome }}=\sum_{i=1}^{n}[]
$$

where $Y_{\text {tincome }}$ is total household income and $S_{i}$ stands for income from source $i$.

Income from NTFPs was calculated by adding cash and non-cash income received from NTFPs, where non-cash income is the non-monetary income or in-kind value of NTFPs consumed by the households for their self-usage and cash income is the value received from selling them. As we suppose that households have market access, both cash income from selling NTFPs and non-cash income were calculated using market prices or the household self-reported value. If the household receives the wages sent by the household members working outside of the study area, that wage is referred to as migration income. Casual labor income is the income received by working as daily laborers receiving daily wages. Other income is the one generated from small business activities such as home shops. In addition, 'off-farm income' was calculated to examine its effect on NTFP dependency. Off-farm income is the combination of all income activities apart from agricultural production income, thus it is calculated by adding migration income, casual labor income, livestock raising income, and income from other small business activities.

For the calculation of crop cultivation income, we use the income definition in [69]:

$$
I=\sum_{i=1}^{n} p_{i} y_{i}-\sum_{j=i}^{m} q_{j} v_{j}
$$

where $I$ is gross income value, namely, (price $x$ quantities of all $n$ products) - total costs (price $x$ quantities) of $\mathrm{m}$ purchased inputs (e.g., seeds, hired labor) including family labor costs. Income from livestock includes the sales of livestock, livestock products, and associated services but excludes incremental stock value changes.

To understand the diversity of income activities in the households, an income diversification index was calculated by using the inverse Simpson index of diversity [70] as implemented in [29,71]:

$$
\text { Index of diversity }=1 / \sum_{i=1}^{N} P_{I}^{2}
$$

where $N$ is the number of different income sources, $P_{1}, P_{2}, \ldots$, and $P_{n}$ represent the proportion of income source $i$ in total household income. The denominator of the index of diversity may be further decomposed as:

$$
\sum_{i=1}^{N} P_{i}^{2}=\left(\frac{I_{1}}{I_{T}}\right)^{2}+\left(\frac{I_{2}}{I_{\mathrm{T}}}\right)^{2}+\cdots+\left(\frac{I_{n}}{I_{T}}\right)^{2}
$$


where $I_{1}, I_{2}, \ldots, I_{n}$ are the values of the different income sources (cash and non-cash) and $I_{T}$ is the total income of household $T$. Thus, a household with a higher number of income-generating activities can be said to be more diversified and will get higher diversity value.

Household poverty was determined based on the annual per capita income of the sampled households compared with the regional poverty line (387,785 Myanmar Kyats (MMK/year) $=\$ 308 /$ year, as of November 2016) for the study area in the Eastern Bago Region estimated in [72]. If the annual per capita income of a household is below the poverty line, then the variable poverty is 1 and 0 otherwise.

\subsection{Empirical Model}

A multiple regression model was developed to explain NTFP dependence as a function of socio-economic and demographic characteristics of the forest-dependent communities. The multiple linear regression equation is specified as:

$$
\hat{Y}=\beta_{0}+\beta_{1} X_{1}+\beta_{2} X_{2}+\cdots+\beta_{p} X_{p}+\varepsilon,
$$

where $\hat{Y}$ is the predicted value of NTFPs dependence, $\beta_{0}$ is the intercept, $\beta_{1} \ldots \beta_{p}$ are the regression coefficients, $X_{1} \ldots X_{p}$ are the predictor variables, and $\varepsilon$ is the disturbance or error term.

In this study, we built three multiple regression models to explain NTFP dependence. Model 1 includes all sampled households; Model 2-1 only includes landowners; Model 2-2 only includes the landless households. The models were estimated using the Statistical Package for Social Sciences IBM SPSS Statistics 23.0 [73].

\section{Results}

\subsection{Descriptive Analysis of the Livelihood of Forest-Dependent Communities}

In the communities surveyed, most households were forest-dependent farmers with $98 \%$ of the households engaged in the exploitation of NTFPs and/or related activities for subsistence and commercial use. According to our survey, around $70 \%$ of households were agricultural land owners, including official and non-official land tenure holders and farm-forestry tenants, while the rest were casual laborers and small business owners. In LMA, almost all land-owning households practiced upland cultivation of rice, groundnut, and sesame, while rice, groundnut and corn were mainly cultivated in HMA and shifting cultivation is their main farming system. The categorical socio-economic characteristics of the respondents are shown in Table 2. Among the respondents, only $3 \%$ were the female-headed households. None of the communities in the study area had access to government-supplied electricity, so more than $50 \%$ of the households used only firewood for cooking, whereas 37\% used only charcoal and the remainder used both wood fuels. Myanmar suffers from significant energy insufficiency as only $13 \%$ of the population has access to electricity [74]. Current electricity consumption in Myanmar is relatively low with only $16 \%$ of people who used electricity for cooking in 2014 , while over $90 \%$ of the rural and $50 \%$ of the urban population use firewood or charcoal for cooking [46,72].

According to the focus group discussion, some of the households' farm lands were lost due to the lack of secure land tenure and most of them expected alternative income opportunities especially in the HMA. Moreover, only a few villages participated in the extension programs such as extension on farming technologies and community forestry and participated in plantations while some did not even notice the programs. Although they showed a positive attitude towards the conservation programs generally, their main concern was getting job opportunities. Key informant interviews with government officials from forest department explained the existence of illegal charcoal making in the study areas and the limitations for monitoring those activities were mainly due to the lack of human capacity and the huge area of forest. 
Table 2. Descriptive statistics for the categorical socio-economic characteristics of sampled households.

\begin{tabular}{|c|c|c|c|c|c|c|c|c|}
\hline \multirow{2}{*}{\multicolumn{2}{|c|}{ Variable }} & \multicolumn{2}{|c|}{$\begin{array}{c}\text { Total } \\
(\mathrm{n}=330)\end{array}$} & \multicolumn{2}{|c|}{$\begin{array}{l}\text { Landowner } \\
(n=238)\end{array}$} & \multicolumn{2}{|c|}{$\begin{array}{l}\text { Landless } \\
(\mathrm{n}=92)\end{array}$} & \multirow[t]{2}{*}{$x^{2}$} \\
\hline & & Freq. $^{a}$ & $\%$ & Freq. $^{a}$ & $\%$ & Freq. $^{a}$ & $\%$ & \\
\hline \multirow{2}{*}{ Gender } & Male & 320 & 97.0 & 233 & 97.9 & 87 & 94.6 & \multirow{2}{*}{$\begin{array}{c}2.510 \\
(p=0.113)\end{array}$} \\
\hline & Female & 10 & 3.0 & 5 & 2.1 & 5 & 5.4 & \\
\hline \multirow{3}{*}{$\begin{array}{l}\text { Fuelwood } \\
\text { usage }\end{array}$} & Charcoal user & 122 & 37.0 & 72 & 30.3 & 50 & 54.3 & \multirow{3}{*}{$\begin{array}{c}16.757 \\
(p=0.000)\end{array}$} \\
\hline & Firewood user & 174 & 52.0 & 140 & 58.8 & 34 & 37.0 & \\
\hline & Both fuels user & 34 & 10.3 & 26 & 10.9 & 8 & 8.7 & \\
\hline \multirow{2}{*}{$\begin{array}{c}\text { Regional } \\
\text { level poverty }\end{array}$} & No & 101 & 30.6 & 79 & 33.2 & 22 & 23.9 & \multirow{2}{*}{$\begin{array}{c}1.961 \\
(p=0.161)\end{array}$} \\
\hline & Yes & 229 & 69.4 & 159 & 66.8 & 70 & 76.1 & \\
\hline \multirow{2}{*}{ Residence } & $\begin{array}{c}\text { Low } \\
\text { mountainous } \\
\text { area }\end{array}$ & 114 & 34.5 & 77 & 32.4 & 37 & 40.2 & \multirow{2}{*}{$\begin{array}{c}1.815 \\
(p=0.178)\end{array}$} \\
\hline & $\begin{array}{c}\text { High } \\
\text { mountainous } \\
\text { area }\end{array}$ & 216 & 65.5 & 161 & 67.6 & 55 & 59.8 & \\
\hline
\end{tabular}

${ }^{a}$ Number of responses.

The independent-samples $t$-test was used to compare the mean difference between landowner and landless groups (see Table 3). The results proved that the landless households had a statistically significant higher share of income from NTFPs $(61.59 \pm 40.52 \%)$ compared to landowners $(29.32 \pm 28.56 \%), \mathrm{t}(328)=-8.13, p=0.000$, explaining that landless households were more dependent on NTFPs than landowners. This leads to a further question, namely, which socio-economic and demographic characteristics other than land ownership are relevant for the dependence on NTFPs. Thus, the descriptive statistics of non-categorical socio-economic characteristics of the respondents are shown in Table 3. The mean age of landowners was 45.91 and 42.37 for the landless. The education levels of households were determined based on their finished schooling years. The mean schooling year of all sampled households was 3.69 which is equivalent to the primary school level. Landowners had more family members than did the landless households. The possibility is that the households with land owned can feed more family members compared to those without land owned. Among landowners, around $90 \%$ of the households grew rice, thus the rice insufficient months were lower than that of landless households. In the case of off-farm income (measured in USD/year), the landless households earned a higher amount (590.77 USD/year) than the landowners (390.06 USD/year). Landowners earned higher amount of per capita income (322.79 USD/year) than that of landless households (303.14 USD/year). There was also a significant difference in income diversity between landowners and the landless. In other words, landowners had more than two sources of income (2.17) whereas the landless households generally had less than two sources of income (1.79).

\subsubsection{Household Annual Subsistence Level and Cash Income from NTFPs}

In this study, we focused on the major NTFPs consumed by households in the study areas. These included bamboo, poles, wild vegetables, medicinal plants, firewood, and charcoal, all of which were collected for subsistence and commercial purposes. The pattern of household NTFP utilization was described in Figure 2. Among the NTFPs extracted, bamboo was the most common, accounting for more than $90 \%$ of the households surveyed, followed by wild vegetables $(85 \%)$, firewood $(62 \%)$, pole $(33 \%)$, and charcoal (33\%). Poles and firewood were extracted only for household use. 
Table 3. Description of socio-economic characteristics of sampled households.

\begin{tabular}{|c|c|c|c|c|}
\hline \multirow{3}{*}{ Variable } & Total Samples & Landowner & Landless & \multirow{3}{*}{$\begin{array}{c}t \text {-Test Statistics, } \\
p \text {-Value }\end{array}$} \\
\hline & $(n=330)$ & $(n=238)$ & $(n=92)$ & \\
\hline & \multicolumn{3}{|c|}{ Mean } & \\
\hline Age & $44.92(12.08)$ & $45.91(11.56)$ & $42.37(13.06)$ & $\begin{array}{c}t_{(149.266)}=-2.277 \\
p=0.024^{* *}\end{array}$ \\
\hline Education & $3.69(2.24)$ & $3.71(2.25)$ & $3.65(2.24)$ & $\begin{array}{c}t_{(166.027)}=-0.210 \\
p=0.834\end{array}$ \\
\hline Family size & $5(1.72)$ & $5(1.79)$ & $4(1.46)$ & $\begin{array}{c}t_{(201.352)}=-3.203 \\
p=0.002\end{array}$ \\
\hline $\begin{array}{l}\text { Rice insufficient } \\
\text { months }\end{array}$ & $1.48(1.88)$ & $1.46(1.85)$ & $1.51(1.95)$ & $\begin{array}{c}t_{(157.810)}=0.206 \\
p=0.837\end{array}$ \\
\hline Off-farm income & 446.01 (793.99) & $390.06(683.80)$ & 590.77 (1015.93) & $\begin{array}{c}t_{(124.201)}=1.748 \\
p=0.083\end{array}$ \\
\hline $\begin{array}{l}\text { NTFP income } \\
\text { composition }\end{array}$ & $28.32(35.38)$ & $29.32(28.56)$ & $61.59(40.51)$ & $\begin{array}{l}t_{(328)}=8.13 \\
p=0.000^{* * *}\end{array}$ \\
\hline $\begin{array}{l}\text { Agricultural land } \\
\text { holding size }\end{array}$ & $1.66(2.25)$ & $2.29(2.35)$ & 0 & $\begin{array}{c}t_{(237)}=-15.067 \\
p=0.000^{* * *}\end{array}$ \\
\hline Per capita income & 317.31 (391.06) & $322.79(430.82)$ & 303.14 (263.05) & $\begin{array}{c}t_{(267.232)}=-0.502 \\
p=0.616\end{array}$ \\
\hline
\end{tabular}

Note: ${ }^{* *} p<0.05$, and ${ }^{* * *} p<0.01$, Standard deviations (in parentheses). Variable refers to the continuous independent and dependent variables included in the regression model. Mean refers to the mean value of each variable for total sampled households, landowner group and landless group. The $t$-value refers to the value of $t$-test statistics. $p$-value tells the likelihood of the differences in means of each variables between two groups.

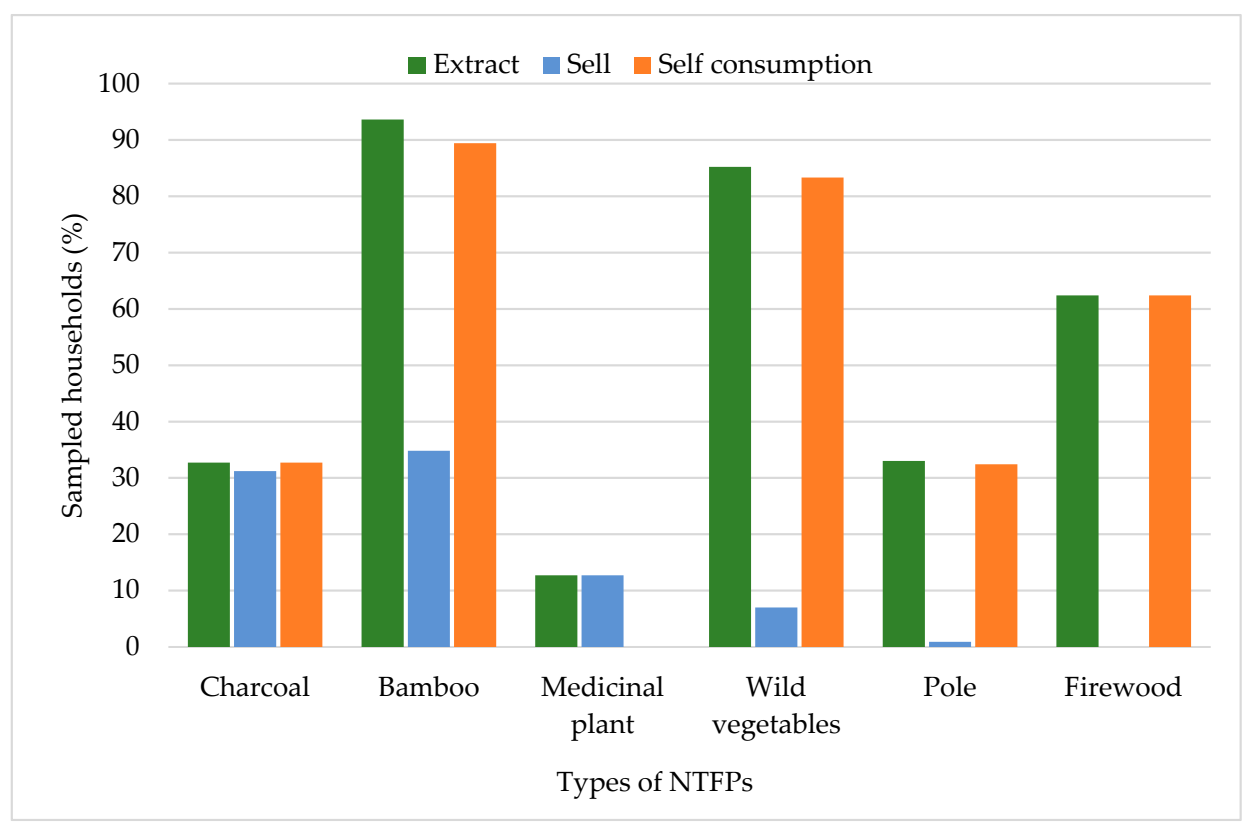

Figure 2. NTFP utilization pattern by sample households. NTFPs: non-timber forest products.

Cash made up $77 \%$ of the total NTFP income while subsistence (non-cash) income was $23 \%$ (Table 4). Cash income from charcoal production was by far the most important source of income for households accounting for $43.8 \%$ of the total NTFP income, followed by bamboo cash income $(30.5 \%)$, and medicinal plant cash income $(2.9 \%)$. Firewood income only accounted for non-cash in the study areas as the households collected firewood for their own use only. Nevertheless, the value for firewood was calculated based on the market price in the nearest township. Income from poles for house construction and wild vegetables was mostly subsistence non-cash income. These results showed which NTFPs the households were more dependent on for income generation. 
Table 4. Household annual income from NTFPs, absolute and relative (\%), Taungoo District, 2016.

\begin{tabular}{|c|c|c|}
\hline NTFP Income Source & Absolute NTFPs Income, ‘ $000 \mathrm{MMK}^{\mathrm{a}}$ & Relative NTFPs Income (\%) \\
\hline Charcoal & 267 & 49.6 \\
\hline Subsistence & 32 & 5.9 \\
\hline Cash & 235 & 43.8 \\
\hline Bamboo & 195 & 36.2 \\
\hline Subsistence & 31 & 5.8 \\
\hline Cash & 164 & 30.5 \\
\hline Poles & 4 & 0.8 \\
\hline Subsistence & 4 & 0.8 \\
\hline Cash & 0 & 0.02 \\
\hline Wild vegetables & 10 & 1.9 \\
\hline Subsistence & 8 & 1.5 \\
\hline Cash & 2 & 0.4 \\
\hline Firewood & 46 & 8.6 \\
\hline Subsistence & 46 & 8.6 \\
\hline Cash & 0 & 0 \\
\hline Medicinal plants & 15 & 2.9 \\
\hline Subsistence & 0 & 0 \\
\hline Cash & 15 & 2.9 \\
\hline
\end{tabular}

a 1 USD = 1259 MMK (Myanmar Kyats), as of November 2016. Subsistence income refers to the non-monetary income or in-kind value of NTFPs consumed by the households for their self-usage. Cash income refers to the monetary income received from selling NTFPs.

\subsubsection{Relative Annual Household Income}

The relative annual household income by source is presented in Figure 3. Households were engaged in at least two sources of income on average while almost $70 \%$ of the households surveyed were below the poverty line. We may at this point postulate that the income sources in the study areas may not have much effect on reducing poverty, thus suggesting that policies should explore the issue of creating better income opportunities. According to the analysis, the share of NTFPs in total income was the largest, accounting for $37 \%$ of total household income, followed by crop cultivation income $(33 \%)$, casual labor income (12\%), and income from raising livestock (10\%). Migration income was the smallest contributor at 3\%, whereas other income such as small business shops and tailoring accounted for $5 \%$. NTFP dependence can range widely depending on the diversity of the household income sources and the geographical area [30,32]. Other studies on different areas of Myanmar [51,53,75] reported that forest and NTFP income contributed to household income by $25-\sim 55 \%$ of household income, while the contribution rate varied with the conditions of different geographical areas and socio-economic characteristics of the households.

\subsection{Livelihood Dependence Estimation}

Three multiple regression models were employed to identify the determinants of the dependence on NTFPs. In Model 1, all sampled respondents $(\mathrm{n}=330)$ were included in the sample and the livelihood dependence on NTFPs was explained by the socio-economic, demographic variables and fuelwood usage described in Table 1. Models 2-1 and 2-2 explained the livelihood dependence on NTFPs for the sub-groups of landowners and landless, respectively. In these two models for sub-groups, all socio-economic, demographic characteristics and fuelwood usage except the size of land owned (LANDAC) were included as explanatory variables. The coefficient of determination $\left(R^{2}\right)$, adjusted $R^{2}$, and $F$-value were used to evaluate model fit. The results of our model estimations and their respective fit were presented in Table 5. 


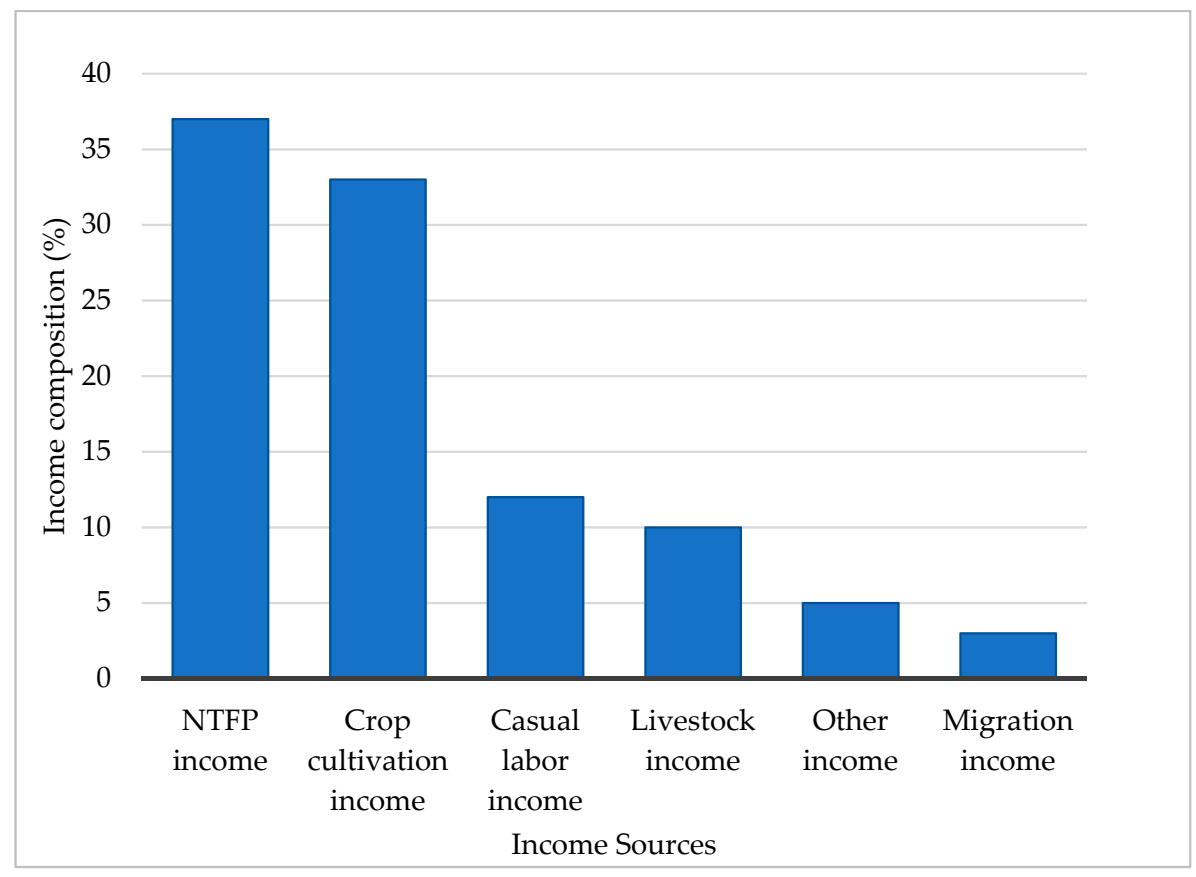

Figure 3. Relative annual household income by income source $(n=330)$, Taungoo District, 2016.

In Model 1, the level of education, land ownership, off-farm income, poverty, and type of fuelwood used were found to be related to livelihood dependence on NTFPs in the expected directions. Specifically, the higher the education level, size of land owned, and income from off-farm activities, the less dependent on NTFPs the households are. Households below the poverty line were more dependent on NTFPs. In terms of energy used, households that used charcoal showed a relatively higher dependence than those that used both charcoal and firewood. However, the households using only firewood were less dependent on NTFPs than those that used both fuels. Although not statistically significant, age, sex, family size, food shortage, and physical conditions of residence area were nevertheless related to dependence on NTFPs in the hypothesized directions.

Model 2-1 predicted that, among landowners, those who had a higher level of education depended more on NTFPs, while those who were under the poverty line, and used only charcoal were more dependent on NTFPs. Though statistically not significant at a higher level, the effect of food shortage showed related to NTFP dependence. The higher coefficient of poverty for landowner group $(B=24.127)$ explained that their option of earning income was extracting NTFPs once they came under the poverty line due to failure in agricultural production. Types of fuelwood used charcoal user (CCUSE) and fuelwood user (FWUSE) were somewhat similar to those for the entire sample (Model 1). However, the directions of the effect of family size in the case of landowners were different from Model 1.

The estimation result for the landless household group (Model 2-2) also revealed that a similar set of variables to Model 1 significantly influenced livelihood dependence on NTFPs. Food shortages, off-farm income, and type of fuelwood used were significant in explaining the dependence on NTFPs. The longer the rice insufficiency periods and the higher off-farm income of the landless households, the more these households depended on NTFPs. Similarly, among the landless households, those who used only charcoal were more dependent on NTFPs. Although not statistically significant at a higher level, the effect of only firewood used was related to NTFP dependence. 
Table 5. Estimation of the effect of socio-economic characteristics and fuelwood usage on NTFP dependence by household group: Full sample, landowners, and landless.

\begin{tabular}{|c|c|c|c|c|c|c|c|c|c|c|c|c|}
\hline \multirow{2}{*}{ Variables } & \multicolumn{4}{|c|}{ Model 1, All Sampled Respondents $(n=330)$} & \multicolumn{4}{|c|}{ Model 2-1, Landowners $(n=238)$} & \multicolumn{4}{|c|}{ Model 2-2, Landless $(n=92)$} \\
\hline & B & Std. Error & $t$-Value & $p$-Value & B & Std. Error & $t$-Value & $p$-Value & B & Std. Error & $t$-Value & $p$-Value \\
\hline (Constant) & 41.865 & 13.014 & 3.217 & $0.001^{* * *}$ & 15.879 & 13.757 & 1.154 & 0.250 & 34.630 & 23.915 & 1.448 & 0.151 \\
\hline AGE & -0.079 & 0.120 & -0.653 & 0.514 & -0.043 & 0.121 & -0.357 & 0.721 & -0.061 & 0.223 & -0.275 & 0.784 \\
\hline SEX & 4.105 & 8.371 & 0.490 & 0.624 & 5.792 & 9.662 & 0.599 & 0.550 & 11.302 & 12.642 & 0.894 & 0.374 \\
\hline EDU & -1.510 & 0.642 & -2.353 & $0.019 * *$ & -1.462 & 0.634 & -2.307 & $0.022^{* *}$ & -1.284 & 1.177 & -1.091 & 0.278 \\
\hline HHSIZE & 0.312 & 0.867 & 0.360 & 0.719 & -0.542 & 0.805 & -0.674 & 0.501 & 2.512 & 2.088 & 1.203 & 0.232 \\
\hline LANDAC & -1.321 & 0.287 & -4.603 & $0.000^{* * *}$ & & & & & & & & \\
\hline RICINSUF & 1.211 & 0.808 & 1.498 & 0.135 & 1.308 & 0.774 & 1.690 & 0.092 & 3.583 & 1.639 & 2.187 & $0.032 * *$ \\
\hline OFFINCOM & -0.007 & 0.002 & -3.676 & $0.000 * * *$ & -0.003 & 0.002 & -1.551 & 0.122 & -0.009 & 0.003 & -3.104 & $0.003^{* * *}$ \\
\hline POV & 9.837 & 3.575 & 2.752 & $0.006^{* * *}$ & 24.127 & 3.565 & 6.768 & $0.000^{* * *}$ & 6.363 & 6.737 & 0.945 & 0.348 \\
\hline RESIDE & 1.578 & 3.172 & 0.498 & 0.619 & 1.430 & 3.096 & 0.462 & 0.645 & 2.941 & 6.658 & 0.442 & 0.660 \\
\hline CCUSE & 21.960 & 5.220 & 4.207 & $0.000^{* * *}$ & 18.849 & 5.197 & 3.627 & $0.000^{* * *}$ & 22.824 & 10.008 & 2.280 & $0.025^{* *}$ \\
\hline \multirow[t]{2}{*}{ FWUSE } & -16.926 & 4.843 & -3.495 & $0.001^{* * *}$ & -11.320 & 4.676 & -2.421 & $0.016^{* *}$ & -18.831 & 10.416 & -1.808 & 0.074 \\
\hline & \multicolumn{4}{|c|}{$\begin{array}{c}\text { Adjusted } R^{2}=49.2 \% \\
F_{11,318}=29.922, \\
\text { Significance level }=0.000 * * * *\end{array}$} & \multicolumn{4}{|c|}{$\begin{array}{c}\text { Adjusted } R^{2}=46.5 \% \\
F_{10,227}=21.596 \\
\text { Significance level }=0.000 * * *\end{array}$} & \multicolumn{4}{|c|}{$\begin{array}{c}\text { Adjusted } R^{2}=62.3 \% \\
F_{10,81}=16.051 \\
\text { Significance level }=0.000 * * *\end{array}$} \\
\hline
\end{tabular}

Note: ${ }^{* *} p<0.05$, and ${ }^{* * *} p<0.01$, Dependent variable $=$ NTFP dependence (relative share of income from NTFPs). 


\section{Discussion}

\subsection{Factors Affecting NTFP Dependence by Forest-Dependent Communities}

In Model 1, five explanatory variables were statistically significant for NTFP dependence in a multiple regression analysis context. The negative effect of education may be due to the fact that more educated households had better access to a wider range of income opportunities and the extraction of NTFPs may not be their main income source. This is consistent with a previous study [52] on Myanmar reporting that households with a low education level were more dependent on the forests. Generally, wealthier households in rural Myanmar communities have more opportunities for education and greater access to farmland. However, the descriptive analysis showed that there was not much difference in education level of landless and landowner groups. Thus, we can postulate that although education showed significance, it may not have an effective measure. It is possible that the households with a higher education level in the study areas had better access to farmland and were more involved in agriculture than in forest activities. Landownership had a negative effect on dependence on NTFPs as well, indicating that the larger the size of the agricultural land, the less the household will depend on NTFPs [29,32]. One can expect that if a household owns more land, there is a higher probability of having both food security and cash income from agricultural farming. The finding that NTFP dependence decreased with increases in off-farm income was consistent with previous results $[53,59,76]$ and was also consistent with our expectation that households who earned higher income from raising livestock, casual labor, and other small businesses would depend less on labor-intensive NTFP extraction activities. The estimation results suggested that poverty was positively related to NTFP dependence as expected, indicating that the households that were under the poverty line depended more on NTFPs as a fall back resource or as a means of income diversification. Previous studies [22,32] supported our findings. In our models, households headed by men were seemingly more dependent on NTFPs, yet it is not statistically significant, which is similar with the previous studies $[57,64]$. This finding is contrary to other findings which argued that female involvement in NTFPs collection is dominant $[62,63,77]$, and higher number of female family labor has higher dependence on NTFPs [60]. We could postulate that this different dependence may rely on the market access, and types of NTFPs mainly collected by households. In the study area, female-headed households sold NTFPs mostly at the local market whereas male-headed households went to the township market to get a better price for their products. Moreover, charcoal making had the highest share of NTFPs income among different NTFPs extracted (Table 4), besides, that activity was mainly conducted by the male households due to the hard work. Thus, there is a high chance of getting higher income from NTFPs for male than female-headed households in the study area. Another possibility may be due to the huge difference in the number of sampled male and female-headed households surveyed.

Our results were also supported by [2], which reported that NTFPs can fulfill several livelihood requirements starting from subsistence to safety nets and cash income to alleviate poverty. The positive effect of charcoal use on the NTFPs dependence implied that among the households that used fuelwoods, those which only used charcoal for subsistence and/or selling were much more dependent on NTFPs for their livelihood than those that used both charcoal and firewood. Among the households that used charcoal for cooking, almost 70\% made charcoal themselves not only for subsistence but also for commercial purposes. This explained the hypothesis that the households were more dependent on NTFPs if they could get non-cash as well as cash benefits as part of their income. As expected, the utilization of firewood alone led to significantly less dependence on NTFPs than for the households that used both fuels. This would imply a similar hypothesis to the one mentioned above where a higher relative income from NTFPs may be expected when the contribution of income from charcoal making was significantly higher than the subsistence income from firewood.

Contrary to our initial hypothesis, age, sex, family size, food shortage, and physical conditions of residence areas were not significantly associated with dependence on NTFPs. We may postulate that since there were limited income opportunities or non-forest income generating options in the 
study areas, then regardless of age, gender, and family size, local people were more dependent on the extraction of NTFPs [30].

The results of Model 2-1 and Model 2-2 showed the comparative effects of socio-economic, demographic characteristics of the respondents and their fuelwood usage who owned agricultural land and those who did not. The charcoal usage was the only significant variable significant in both models, and was consistent with the result of Model 1. As in the case of Model 1, education level, food shortage, off-farm income, and poverty were significantly associated with NTFP dependence in Models 2-1 and 2-2. The positive significant effect of poverty on the dependence on NTFPs in Model 2-1 implied the same effect in terms of direction, but with a higher magnitude than in Model 1. Therefore, among the landowners, those who were under the poverty line tend to extract NTFPs as a fall back option in times of emergency, thus increasing their dependence on NTFPs [22,32]. Longer periods of rice insufficiency (RICINSUF) made the landless group in Model 2-2 more dependent on NTFPs. This is possible because most of the landless people may be rice-insufficient due to their lack of agricultural land so they tended to engage more in forest extraction activities. This hypothesis was supported by previous studies $[30,65]$. Similar to Model 1, having a higher amount of off-farm income (OFFINCOM) had a negative correlation with NTFP dependence in Model 2-2. This implied that among the landless people, those who had higher off-farm income were less dependent on NTFPs [29]. It is therefore likely that the presence of more diverse sources of income for the landless people would help reduce the overexploitation of NTFPs.

The comparison between Models 2-1 and 2-2 highlighted the differences in terms of the dependence of landowners and the landless people on NTFPs with respect to their socio-economic, demographic characteristics and fuelwood used. As these models showed fuelwood usage it could help anticipate NTFP exploitation trends in the study areas. Overall, landownership, off-farm income, poverty and fuelwoods used were the most impactful variables on NTFPs for the study areas. These findings may help to develop PAMs that would help reduce overexploitation of NTFPs in forest-dependent areas.

\subsection{Policy Implications for REDD+}

The findings from our study showed that poverty, food insecurity, land ownership, fuelwood usage, and low education were the main causes of dependency on NTFPs in rural communities in Myanmar (Model 1). Obviously, the study area was located in a region with limited development, where the average finished schooling years of the respondents was 3.6 years, almost $70 \%$ of the respondents lived under the poverty line, $45 \%$ reported rice insufficiency, $30 \%$ had no agricultural land, and all depended solely on charcoal and firewood for cooking. Given this situation, addressing the drivers of overexploitation of NTFPs could consider the livelihood of local communities and their living conditions to develop effective policies and measures. Well-designed and comprehensive policies are needed to reduce overexploitation of NTFPs in a socially, economically, and environmentally sustainable way. For this reason, we suggested the following policy implications conceived with the idea of long-term benefits for both local communities and the surrounding forests and the improvement of existing policies.

\subsubsection{Policy Implications for Poverty}

The results revealed that NTFPs contributed substantially to the income of forest-dependent communities as the average NTFP income share in total annual household income was $37 \%$ (see Figure 3 ). Still, almost $3 / 4$ of the respondents lived below the regional poverty line. In addition, our study revealed that households below the poverty line were more dependent on NTFPs. This condition was the root cause behind the increasing exploitation of NTFPs by the communities, thus increasing forest degradation in the study area. An important conclusion we can draw from our results combined with our examination from the focus group discussion was that the first reliable income option for the recently landless respondents was the exploitation of NTFPs due to the lack of alternative income opportunities in the area. Hence, policies creating non-farm employment opportunities would help 
local communities become less dependent on NTFPs [78] while raising their income beyond the subsistence level. Support for raising subsistence livestock would also be an alternative option as it could create both cash and in-kind income while enabling the possibility to save for future needs. In addition, providing technologies for adding value to NTFPs as well as developing the appropriate marketing channels for those products [79] or supporting the extension services on harvesting NTFPs in a sustainable way could help not only increase their benefits but also reduce forest degradation.

\subsubsection{Policy Implications for Food Security}

The respondents in the study area suffered from rice insufficiency for 1.5 months on average per year. A high percentage of food insecurity among landowners revealed the need for agricultural development policies in rural communities. Agricultural policies that focus on crop diversification or agroforestry would help increase their production and ensure the yield [80]. However, these policies could be implemented at the national level to prevent conversion of forestland to agricultural land use or other related activities. Such policies could be accomplished through the support of agricultural technologies, some of which have already been proposed by national specialists [80], and the dissemination of information. Despite no significant difference in terms of food insecurity between landless and landowners, agricultural land allocation or providing land leases for the landless people to do agroforestry could help them to not only generate a steady flow of rice for consumption, but would also help reduce overexploitation of NTFPs.

\subsubsection{Policy Implications for Land Tenure Security}

Our analysis reported that a proportion of NTFP income in the case of landless people was twice as much as that of landowners. As income from agricultural production was the second highest contribution to household total income, policy interventions allocating land or providing land lease agreements especially formulated for the landless in forest-dependent households could help reduce their dependency on NTFPs. Among landowners, some were farm-forestry tenants practicing agroforestry while others were non-official landholders practicing shifting cultivation. Previous studies suggested that forest tenure was the most critical factor behind overharvesting of NTFPs [81,82]. Thus, social safeguards such as land tenure security and recognition of traditional land use rights could be secured to implement REDD+ within the framework of Myanmar's national land use policy as a means to reduce forest degradation at the national level [83-85].

\subsubsection{Policy Implications for Energy Supply}

All the communities in the study area had no access to electricity and solely depended on charcoal and firewood for cooking. The Myanmar energy poverty survey reported by [86] highlights the lack of awareness about renewable energy equipment and alternative fuels by rural households [74]. One study conducted in the same study areas in the Yaedarshae township revealed the effect of using multiple fuels (mainly fuelwood, gas, and electricity) in urban areas on reducing the consumption of firewood and charcoal [54], thus lessening the adverse impact on the forests. Pode et.al [87] showed the possibility of the rice husk biomass power system as an affordable option for rural electrification in Myanmar. Unless alternative fuels are provided, the rate of degradation of Myanmar forests will be exacerbated. Thus, energy policies in Myanmar could focus on introducing and providing incentives for the adoption of alternative fuels such as biomass waste and technologies on the biomass based power system, as well as incentivizing the production and distribution of efficient cook stoves to reduce charcoal and firewood consumption at the national level $[16,88]$. Such policies could be implemented through extension services concentrating on how to effectively and easily use alternative fuels and/or the improved cooking stoves. Technologies for building and improving cooking stoves could be provided for long-term distribution. In addition, the development of fuelwood plantations with participation by local communities could be implemented and accompanied with monitoring and follow-up activities. 


\subsubsection{Policy Implications for Capacity Building}

More than 2/3 of land owners in the study areas were under the poverty line, thus highlighting the need for intensive agriculture technologies to increase the productivity. As practicing intensive agriculture is an alternative to NTFP extraction and may in fact be beneficial for reducing NTFP extraction [89,90], agricultural policy could focus on providing extension services related to improved cultivation practices in order to increase crop yields.

In Yaedarshae township, more than $50 \%$ and almost $40 \%$ of the rural population used charcoal and firewood for cooking respectively [54]. Our study revealed the high consumption of fuelwood in the study area. Accordingly, charcoal production was conducted not only by local residents but also by the short-term migrants and business owners from suburban areas. Thus, energy strategies could also focus on providing economic support or in-kind supplies for user access to alternative fuels and technologies for the distribution of efficient stoves to reduce the stress on NTFPs [91].

The low education level of the households, and their low participation in the extension programs explained the need to conduct the effective extension services which can meet the priorities of the local communities through increasing their capacity. Focus group discussions with local communities reported that only a few villages participated in extension services concerning agricultural farming technologies, establishing plantations and community forestry related information. Previous studies revealed that local communities were aware of environmental problems but did not seek involvement in environmental programs due to lack of interest, time, awareness, and knowledge level [92-95]. Polices could emphasize building environmental awareness and knowledge on the part of fuelwood users and producers. As illegal logging (including charcoal production) and firewood collection are the direct drivers of forest degradation [16], as well as their high contribution to the livelihood of local communities, policies for reducing wood consumption by locals with a careful consideration of an alternative energy supply could be a solution to the current problem of forest degradation in Myanmar. This could be conducted at the local level through the provision of guidelines and technologies for the extraction and management of NTFPs in a sustainable way, in addition to educational training on the adverse effects of fuelwood utilization not only on the environment but also on family health [16].

\subsection{Suggestions for Developing Potential PAMs}

To prevent anthropogenic intrusion into the natural ecological systems and to take action against climate change, the developing countries participating in the UN-REDD program were encouraged to develop and implement PAMs to support climate change mitigation and adaptation actions. PAMs can not only deal with the main activities of REDD+, but can also bring about an integrated rural development while helping mitigate climate change. We developed a potential PAMs package based on the major policy implications mentioned above to address the overexploitation of NTFPs (see Figure 4). This figure explained how the main causes of overexploitation of NTFPs (poverty, food insecurity, land tenure insecurity, energy inaccessibility (electricity) and lack of capacity-low education) could be addressed by means of potential PAMs. The following combination of PAM suggestions could be considered to solve the problems discussed above. 


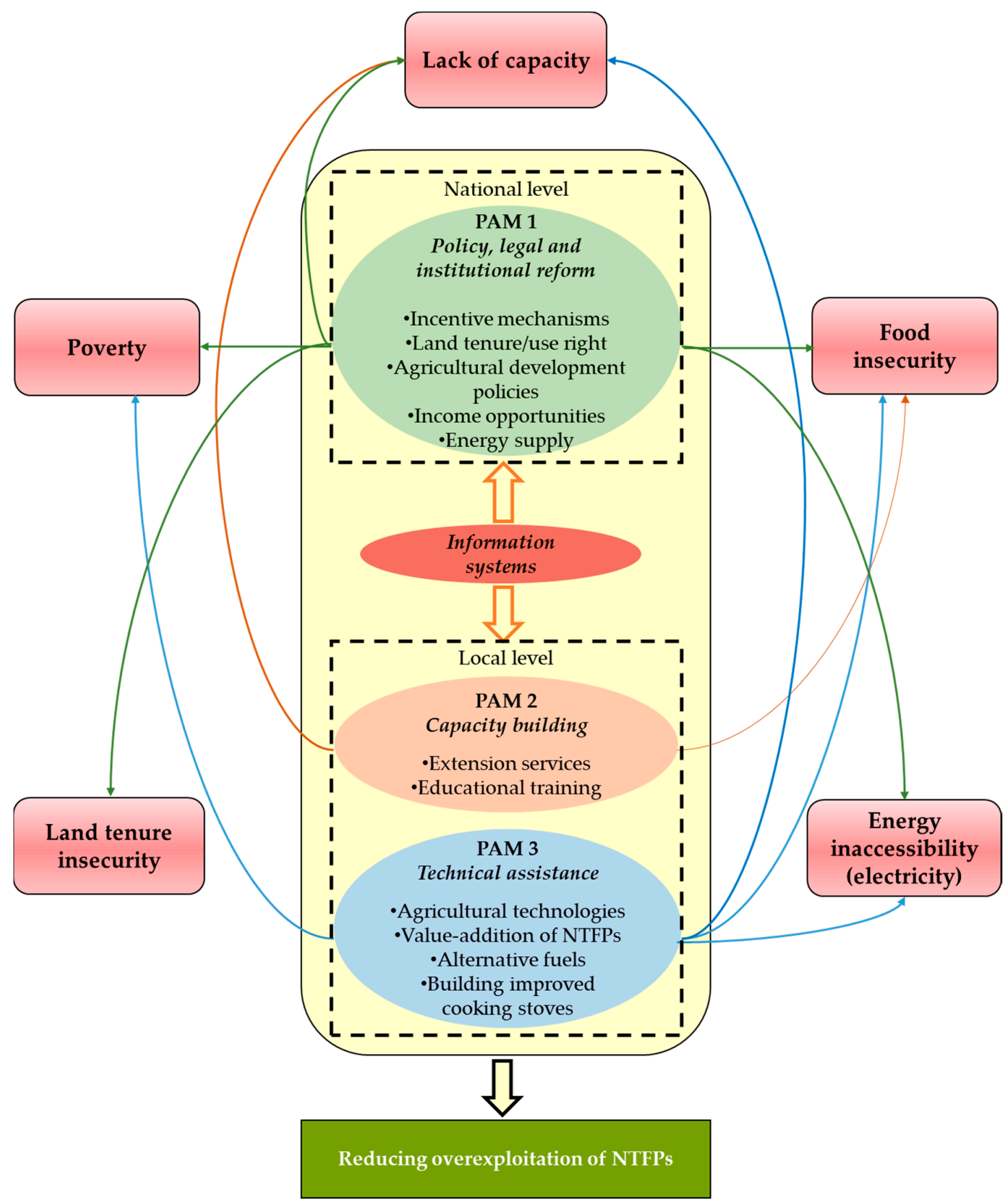

Figure 4. Illustration of potential combined package of policies and measures to solve main problems of NTFPs overexploitation. PAM: policies and measures, Source: Adapted from $[15,16]$.

Combined PAM 1: To reduce overexploitation of NTFPs, we need to reform policy, law and institutions such that incentive mechanisms, land tenure and land use rights can be improved, and agricultural productivity, income opportunities and energy supply are developed at the national level.

The long-term production of forest products lies at the core of sustainable forest conservation while overexploitation and the extraction in an unsustainable way lead to the degradation of forests. Recently, the value of NTFPs has been recognized along with their contribution to the local and national economy. At the same time, stress on forests due to the exploitation of NTFPs has increased due to poverty, food insecurity, land tenure insecurity, energy inaccessibility and lack of capacity-low education. As REDD+ has the potential to be a new paradigm for both conservation and livelihood development [96], PAMs should take into account this two-way feedback relationship and develop 
win-win situations through the provision of incentives. Securing land tenure, providing enough land leases to do agroforestry by participating in government plantation programs, or creating income opportunities, could help increase participation in conservation programs, consequently reducing overexploitation of NTFPs [95]. Indeed, long-term consideration for the communities could assist to ensure such win-win situations. According to key informant interviews, charcoal making has been practiced both legally and illegally in the study area. However, the data on legal or illegal production of charcoal by households were not obtained in our survey. This situation stresses the need for legal reform and action against individuals who focus on maximizing short-term benefits at the expense of the long-term sustainability of NTFPs. Apart from this, the research on NTFPs and fuelwood consumption by households and their perceptions on their utilization warrants further study.

Combined PAM 2: To solve the problem of food insecurity and lack of capacity, we need to conduct capacity building for forest-dependent communities at the local level.

Common property resources can be overexploited if tenure systems are weakened or where governance or enforcement mechanisms are ineffective [97]. In Myanmar, common property NTFPs enable forest-dependent communities to harvest more forest products and gradually making them faced with an additional challenge of sustaining their livelihoods, due to overexploitation of forest resources in the land tenure system lacking. The security of access to NTFPs could be carefully increased [97]. As sole dependency on forest products could not provide enough income to the communities [17], extension services on extraction and management of NTFPs in a sustainable way, agricultural technologies to increase crop production, and educational training on environmental awareness would help reduce food insecurity and increase the capacity of communities.

Combined PAM 3: To solve the problem of energy supply, poverty, food insecurity and lack of capacity, we need to offer technical assistance to forest-dependent communities at the local level.

Despite the fact that charcoal making provided tangible economic benefits to the communities (see Table 4), it had a severe impact on the environment due to unsustainable harvesting and the selective harvesting of trees $[35,98]$. Thus, it is important to include this understanding in policy discussions. In addition, a social-environmental strategic assessment could be conducted. Moreover, technologies related to the use of alternative fuels, building improved cooking stoves [16] could help increase the energy supply, while value-addition to NTFPs together with conservation programs and environmental awareness raising would reduce the overexploitation of NTFPs.

There is increasing evidence that forest policies and management strategies do not work in developing countries with large forest areas [77]. As Myanmar has a large forest area with weak technology development and little human capacity, investigation and follow-up activities to detect and prevent illegal charcoal making cannot be conducted effectively, especially in the remote HMAs. As seen in our survey, households residing in HMAs were more dependent on NTFPs than those residing in LMA. To have effective regulation, follow-up activities and field investigations concerning potential PAMs are imperative and should be strengthened for the sustainability of all PAMs. Overall, capacity building of government staff and research support would be crucial for PAMs to address the overexploitation of NTFPs.

\section{Conclusions}

Myanmar is one of the REDD+ implementing countries contributing to green development by protecting environmental resources, promoting reforestation and forest restoration, improving livelihoods of forest-dependent communities, and adapting to climate change. Reducing the degradation of existing overexploited forests and preventing future forest degradation is one of the objectives of the Myanmar National REDD+ strategy [16]. To achieve this goal, developing and then implementing effective PAMs is crucial. This paper set out to generate data and information for the development of REDD+ PAMs. Policy implications for REDD+ to reduce overexploitation of NTFPs and forest degradation were considered in this study based on NTFP dependency by forest-dependent communities, specifically for the area of the Taungoo District, Bago Region. 
Overexploitation of NTFPs leads to forest degradation and the causes vary according to local conditions. We investigated the factors influencing dependence on NTFPs and explored potential PAMs. Our results showed that NTFPs contributed the most to total household income and the main contribution to NTFPs came from charcoal making and bamboo selling. It is worth noting that among sampled households, those who had a lower education level, less agricultural land, less income from off-farm activities, and those who lived under the poverty line, as well as those who used only charcoal, were more dependent on NTFPs. Also, among landowners, those who had a lower education level and were under the poverty line, were more dependent on NTFPs. Similarly, among landless people, those who were with longer periods of rice insufficiency, had less income from off-farm activities and those who used charcoal had a higher dependence on NTFPs.

From the study results, the effects of landownership, poverty, off-farm opportunities and fuelwood used on NTFP dependence remind policy makers to take into account local people's livelihoods while considering the sustainable management of forest at the national level. The suggestions went to paying more attention to creating income generating activities, land tenure security and technologies for alternative fuels integrating in the REDD+ PAMs through increasing the awareness of local communities and participation in conservation programs. As implementing these strategies on human-environment conservation is long-term task, it is challenging for policy makers to fulfill the priority of local communities focused on food security and subsistence income while implementing sustainable forest management. Thus, the cooperation of line ministries would be needed. As energy supply has a huge impact on forest degradation, the cooperation between the forestry sector and energy sector would make effective strategies on reducing fuelwood usage.

Policy makers should refer to the socio-economic and demographic characteristics of forest-dependent communities in considering how PAMs can be suitable for a specific set of social conditions at the local level. Our study provided this information by shedding light on potential PAMs based on empirical factors related to the dependence of forest-dependent communities on NTFPs and on the problem of overexploitation of NTFPs. Our results also provided an expanded set of policy implications to be considered in REDD+ implementation by highlighting the underlying causes of the dependence on NTFPs. In fact, our analysis identified the empirical factors that determined this dependence.

The scientific information gained could facilitate better targeting of policies and for more socially and ecologically sustainable forest management. The results from our study would be relevant for other REDD+ implementing countries with similar conditions of local communities. However, it must be kept in mind that this study also has limitations related to the representativeness of the two townships selected. Future study should investigate the impact of potential PAMs in different socio-economic contexts so that effective and suitable PAMs could be employed to accurately target the drivers of deforestation and forest degradation at a larger scale.

Author Contributions: K.T.S. conceived, designed the study, conducted the survey, analyzed the data, interpreted the results, and wrote the first manuscript. Y.Y.-C. supervised the overall research, interpreted the results, and reviewed and edited the draft manuscript.

Funding: This research was supported by a fellowship program from the International Tropical Timber Organization (ITTO) and the Carbon Sink Graduate Program at Seoul National University supported by the Korea Forest Service and Korea Forestry Promotion Institute.

Acknowledgments: We are grateful to the International Tropical Timber Organization (ITTO), the carbon sink graduate program from the Korea Forest Service (KFS) and Korea Government Scholarship Program (KGSP) for granting the scholarship for the Ph.D study for the first author. We are also grateful to the Forest Department, Ministry of Natural Resources and Environmental Conservation (MOECAF) in Myanmar for providing the available information as well as the Taungoo District forest departments for their generous help during the survey. We are also thankful for the efforts of our wonderful survey team receiving the available data. Lastly, our great gratitude is extended to all respondents of the survey for sharing their knowledge and opinions with us.

Conflicts of Interest: The authors declare no conflict of interest. The funding sponsors had no role in the design of the study; in the collection, analyses, or interpretation of data; in the writing of the manuscript and in the decision to publish the results. 


\section{References}

1. Hardin, G. The Tragedy of the Commons. Science 1968, 162, 1243-1248. [PubMed]

2. Shackleton, S.; Delang, C.O.; Angelsen, A. From Subsistence to Safety Nets and Cash Income: Exploring the Diverse Values of Non-timber Forest Products for Livelihoods and Poverty Alleviation. In Non-Timber Forest Products in the Global Context; Shackleton, S., Shackleton, C., Shanley, P., Eds.; Springer: Berlin/Heidelberg, Germany, 2011; p. 289, ISBN 9783642179822.

3. Angelsen, A.; Wunder, S. Exploring the Forest-Poverty Link: Key Concepts, Issues and Research Implications; Occasional paper 40; Center for International Forestry Research: Bogor, Indonesia, 2003; ISSN 0854-9818.

4. Alcorn, J.B. Economic Botany, Conservation, and Development: What's the Connection? Ann. Missouri Bot. Gard. 1995, 82, 34-46. [CrossRef]

5. Herring, R.J. The Commons and Its "Tragedy" as Analytical Framework: Understanding Environmental Degradation; Northwestern University: Evanston, IL, USA, 1988.

6. FAO. Assessing Forest Degradation: Towards the Development of Globally Applicable Guidelines, Forest Resources Assessment Working Paper 177; Food and Agriculture Organization of the United Nations: Rome, Italy, 2011.

7. Weatherley-Singh, J.; Gupta, A. Drivers of deforestation and REDD+ benefit-sharing: A meta-analysis of the (missing) link. Environ. Sci. Policy 2015, 54, 97-105. [CrossRef]

8. Hosonuma, N.; Herold, M.; De Sy, V.; De Fries, R.S.; Brockhaus, M.; Verchot, L.; Angelsen, A.; Romijn, E. An assessment of deforestation and forest degradation drivers in developing countries. Environ. Res. Lett. 2012, 7, 4009. [CrossRef]

9. Kissinger, G.; Herold, M.; De Sy, V.; Angelsen, A.; Bietta, F.; Bodganski, A.; Boucher, D.; Boyle, T.; Brickell, E.; Defries, R.; et al. Drivers of Deforestation and Forest Degradation: A Synthesis Report for REDD+ Policy Makers; Government of the UK and Norway; Lexeme Consulting: Vancouver, BC, Canada, 2012.

10. Kissinger, G.; San, P.P.; Arnold, F.; Mon, M.S.; Min, N.E.E. Identifying Drivers of Deforestation and Forest Degradation in Myanmar; Myanmar REDD Programme: Yezin, Myanmar, 2017.

11. UNFCCC. Report of the Conference of the Parties on its Thirteenth Session, Held in Bali from 3 to 15 December 2007. 2007, pp. 1-60. Available online: http://Unfccc.Int/Resource/Docs/2007/Cop13/Eng/06a01.Pdf (accessed on 2 May 2019).

12. Angelsen, A.; Brockhaus, M.; Sunderlin, W.D.; Verchot, L.V. Analysing REDD+: Challenges and Choices; Center for International Forestry Research: Bogor, Indonesia, 2012; ISBN 9786028693806.

13. Murphy, D. Safeguards and Multiple Benefits in a REDD+ Mechanism; International Institute for Sustainable Development: Winnipeg, MB, Canada, 2011; pp. 1-29.

14. Myanmar REDD+ Programme. Myanmar REDD|Myanmar REDD. Available online: http://www.myanmarredd.org/ (accessed on 19 July 2018).

15. Hugel, B.; Devalue, K.; Scriven, J.; Halverson, L.; Labbate, G.; Hicks, C.; Walcott, J.; Chiu, M.; Vickers, B.; Eggerts, E. Redd+ Academy Learning Journal, Module 7: Policies and Measures for REDD+ Implementation, 2; United Nations Enviornment Program, Châtelaine: Geneva, Switzerland, 2017; ISBN 9789280736472.

16. Myanmar REDD+ Program. National REDD+ Strategy Myanmar, Draft. 2017. Available online: http: //www.myanmar-redd.org/warsaw-framework/nsap (accessed on 2 May 2019).

17. Than, K.Z.; Wen, Y.; Zaw, Z. Exploring Socioeconomic Impacts of REDD-plus Pilot Program to Rural Livelihoods: Comparative Study of Yedashae and Oaktwin Townships in Bago Region of Myanmar. Int. J. Sci. 2016, 2, 28-41.

18. DeBeer, J.H.; McDermott, M.J. The Economic Value of Non-timber Forest Products in Southeast Asia; The Netherlands Committee for IUCN: Amsterdam, The Netherlands, 1996; p. 200.

19. Angelsen, A.; Jagger, P.; Babigumira, R.; Belcher, B.; Hogarth, N.J.; Bauch, S.; Börner, J.; Smith-Hall, C.; Wunder, S. Environmental Income and Rural Livelihoods: A Global-Comparative Analysis. World Dev. 2014, 64, S12-S28. [CrossRef]

20. Agrawal, A.; Cashore, B.; Hardin, R.; Shepherd, G.; Benson, C.; Miller, D. Economic Contributions of Forests, Background Paper 1. In Proceedings of the United Nations Forum on Forests Report on the tenth session, Istanbul, Turkey, 8-19 April 2013; pp. 1-127.

21. Costanza, R.; D’Arge, R.; de Groot, R.; Farber, S.; Grasso, M.; Hannon, B.; Limburg, K.; Naeem, S.; O’Neill, R.V.; Paruelo, J.; et al. The value of the world's ecosystem services and natural capital. Nature 1998, 387, $253-260$. [CrossRef] 
22. McElwee, P.D. Forest environmental income in Vietnam: Household socioeconomic factors influencing forest use. Environ. Conserv. 2008, 35, 147-159. [CrossRef]

23. Reddy, S.R.C.; Chakravarty, S.P. Forest dependence and income distribution in a subsistence economy: Evidence from India. World Dev. 1999, 27, 1141-1149. [CrossRef]

24. Schaafsma, M.; Morse-Jones, S.; Posen, P.; Swetnam, R.D.; Balmford, A.; Bateman, I.J.; Burgess, N.D.; Chamshama, S.A.O.; Fisher, B.; Freeman, T.; et al. The importance of local forest benefits: Economic valuation of non-timber forest products in the eastern Arc mountains in Tanzania. Glob. Environ. Chang. 2014, 24, 295-305. [CrossRef]

25. Sunderlin, W.D.; Belcher, B.; Santoso, L.; Angelsen, A.; Burgers, P.; Nasi, R.; Wunder, S. Livelihoods, forests, and conservation in developing countries: An overview. World Dev. 2005, 33, 1383-1402. [CrossRef]

26. Mullan, K. The Value of Forest Ecosystem Services to Developing Economies; GCD Working Paper; Center for Global Development: Washington, DC, USA, 2014.

27. Akanni, K.A.; State, O. Economic Benefits of Non-Timber Forest Products Among Rural Communities in Nigeria. Environ. Nat. Resour. Res. 2013, 3, 19-26. [CrossRef]

28. Croitoru, L. Valuing the non-timber forest products in the Mediterranean region. Ecol. Econ. 2007, 63, 768-775. [CrossRef]

29. Heubach, K.; Wittig, R.; Nuppenau, E.A.; Hahn, K. The economic importance of non-timber forest products (NTFPs) for livelihood maintenance of rural west African communities: A case study from northern Benin. Ecol. Econ. 2011, 70, 1991-2001. [CrossRef]

30. Uberhuaga, P.; Smith-Hall, C.; Helles, F. Forest income and dependency in lowland Bolivia. Environ. Dev. Sustain. 2012, 14, 3-23. [CrossRef]

31. Adam, Y.O.; Mirghani, A.; Tayeb, E.L. Forest Dependency and its Effect on Conservation in Sudan: A Case of Srf-Saaid Reserved Forest In Gadarif State. Agric. For. 2014, 60, 107-121.

32. Vedeld, P.; Angelsen, A.; Bojö, J.; Sjaastad, E.; Kobugabe Berg, G. Forest environmental incomes and the rural poor. For. Policy Econ. 2007, 9, 869-879. [CrossRef]

33. Myers, N. Tropical Forests: Much More Than Stocks of Wood. J. Trop. Ecol. 1988, 4, 209-221. [CrossRef]

34. Solomon, M.M. Importance of non-timber forest production in sustainable forest management, and its implication on carbon storage and biodiversity conservation in Ethiopia. Int. J. Biodivers. Conserv. 2016, 8, 269-277. [CrossRef]

35. Chidumayo, E.N.; Gumbo, D.J. The environmental impacts of charcoal production in tropical ecosystems of the world: A synthesis. Energy Sustain. Dev. 2013, 17, 86-94. [CrossRef]

36. Datta, S.K.; Sarkar, K. NTFPs and Their Commercialization Issues from the Perspective of Rural Livelihood and the State of Forest Resources: A Study of the Ranibundh Forest Range in West Bengal, India. J. Sustain. For. 2012, 31, 640-660. [CrossRef]

37. Murali, K.S.; Shankar, U.; Shaanker, R.U.; Ganeshaiah, K.N.; Bawa, K.S. Extraction of non-timber forest products in the forests of Biligiri Rangan Hills, India 2. Impact of NTFP extraction on regeneration, population structure, and species composition. Econ. Bot. 1996, 50, 252-269. [CrossRef]

38. Ndangalasi, H.J.; Bitariho, R.; Dovie, D.B.K. Harvesting of non-timber forest products and implications for conservation in two montane forests of East Africa. Biol. Conserv. 2007, 134, 242-250. [CrossRef]

39. Shankar, U.M.A.; Murali, K.S.; Shaanker, R.U.M.A.; Ganeshaiah, K.N.B. Extraction of Non-Timber Forest Products in the Forests of Biligiri Rangan Hills, India 4. Impact on Floristic Diversity and Population Structure in a Thorn Scrub Forest. Econ. Bot. 1998, 52, 302-315. [CrossRef]

40. Dao, T.H.H.; Hölscher, D. Impact of non-timber forest product use on the tree community in north-western Vietnam. Forests 2018, 9, 431. [CrossRef]

41. Scriven, J. Developing REDD+ policies and measures from the bottom-up for the buffer zones of Amazonian protected areas. Environ. Dev. Sustain. 2012, 14, 745-765. [CrossRef]

42. FAO. Global Forest Resources Assessment 2015-Desk Reference; Food and Agriculture Organization of the United Nations: Rome, Italy, 2015; ISBN 9789251088265.

43. FAO. Global Forest Resources Assessment 2015-Working Paper 180, Terms and Definitions; Food and Agriculture Organization of the United Nations: Rome, Italy, 2015.

44. FAO. Global Forest Resources Assessment 2010-Main Report, Forestry Paper 163; Food and Agriculture Organization of the United Nations: Rome, Italy, 2010; 350p. 
45. Asia Indigenous Peoples' Pact (AIPP); The International Work Group for Indigenous Affairs (IWGIA); Asian Forum for Human Rights and Development (FORUM-ASIA). AIPP Asean's Indigenous People; IWGIA: Chiang Mai, Thailand, 2010; pp. 1-20.

46. Myanmar Department of Population. The 2014 Myanmar Population and Housing Census. The Union Report: Census Report; Ministry of Immigration and Population: Naipyidó, Myanmar, 2015; Volume 2.

47. Rao, M.; Rabinowitz, A.; Khaing, S.T. Status review of the protected-area system in Myanmer, with recomendations for conservation planning. Conserv. Biol. 2002, 16, 360-368. [CrossRef]

48. Myanmar Ministry of Forestry. Myanmar Forest Law (1992); The State Law and Order Restoration Council: Naipyidó, Myanmar, 1992.

49. Myanmar Ministry of Natural Resources and Environmental Conservation. Community Forestry Instructions (2016); Ministry of Natural Resources and Environmental Conservation: Naipyidó, Myanmar, 2016.

50. Forest Department of Myanmar. District Level Forest Management Plan (2016-2017 to 2025-2026), Taungoo District, Bago Division Part 1; Ministry of Natural Resources and Enviornmental Conservation: Naipyidó, Myanmar, 2015.

51. Aung, P.S.; Adam, Y.O.; Pretzsch, J.; Peters, R. Distribution of forest income among rural households: A case study from Natma Taung national park, Myanmar. For. Trees Livelihoods 2015, 24, 190-201. [CrossRef]

52. Hlaing, Z.C.; Kamiyama, C.; Saito, O. Interaction between rural people ' s basic needs and forest products: A case study of the Katha District of Myanmar. Int. J. For. Res. 2017, 2017, 1-13.

53. Moe, K.T.; Liu, J. Economic Contribution of Non-timber Forest Products (NTFPs) to Rural Livelihoods in the Tharawady District of Myanmar. Int. J. Sci. 2016, 2, 12-21.

54. Win, Z.C.; Mizoue, N.; Ota, T.; Kajisa, T.; Yoshida, S. Consumption rates and use patterns of firewood and charcoal in urban and rural communities in Yedashe Township, Myanmar. Forests 2018, 9, 429. [CrossRef]

55. Bhagwat, T.; Hess, A.; Horning, N.; Khaing, T.; Thein, Z.M.; Aung, K.M.; Aung, K.H.; Phyo, P.; Tun, Y.L.; Oo, A.H.; et al. Losing a jewel-Rapid declines in Myanmar's intact forests from 2002-2014. PLoS ONE 2017, 12, 1-22. [CrossRef] [PubMed]

56. MIMU Myanmar Topographic Map. Available online: http://themimu.info/gis-resources (accessed on 2 May 2019).

57. Vedeld, P.; Sjaastad, E.; Angelsen, A.; Kobugabe Berg, G. Counting on the Environment. Forest Income and the Rural Poor; Environmental Economics Series; The World Bank: Washington, DC, USA, 2004; Volume 98.

58. Kamanga, P.; Vedeld, P.; Sjaastad, E. Forest incomes and rural livelihoods in Chiradzulu District, Malawi. Ecol. Econ. 2009, 68, 613-624. [CrossRef]

59. Illukpitiya, P.; Yanagida, J.F. Role of income diversification in protecting natural forests: Evidence from rural households in forest margins of Sri Lanka. Agrofor. Syst. 2008, 74, 51-62. [CrossRef]

60. Viet Quang, D.; Nam Anh, T. Commercial collection of NTFPs and households living in or near the forests. Ecol. Econ. 2006, 60, 65-74. [CrossRef]

61. Sarker, D.; Das, N. Women's Participation in Foestry: Some Theoretical Issues. Econ. Polit. Wkly. 2002, 37, 4407-4412.

62. Tee, T.N.; Edet, D.I.; Osang, H. Gender analysis of non-timber forest products utilization by neighborhood communities of cross-river national park. J. Agric. For. Soc. Sci. 2014, 12, 195. [CrossRef]

63. Timko, J.A.; Waeber, P.; Kozak, R.A. The socio-economic contribution of non-timber forest products to rural livelihoods in Sub-Saharan Africa: Knowledge gaps and new directions. Int. For. Rev. 2010, 12, $284-294$. [CrossRef]

64. Mamo, G.; Sjaastad, E.; Vedeld, P. Economic dependence on forest resources: A case from Dendi District, Ethiopia. For. Policy Econ. 2007, 9, 916-927. [CrossRef]

65. Prado Córdova, J.P.; Wunder, S.; Smith-Hall, C.; Börner, J. Rural income and forest reliance in highland Guatemala. Environ. Manag. 2013, 51, 1034-1043. [CrossRef]

66. Cavendish, W. Quantitative methods for estimating the economic value of resource use to rural households. Uncovering the hidden harvest: Valuation methods for woodland and forest resources. In Uncovering the Hidden Harvest: Valuation Methods for Woodland and Forest Resources; Earthscan Publications Ltd.: London, UK, 2002; pp. 17-65, ISBN 1-85383-809-8.

67. Win, Z.C.; Mizoue, N.; Ota, T.; Kajisa, T.; Yoshida, S.; Oo, T.N.; Ma, H.O. Differences in consumption rates and patterns between firewood and charcoal: A case study in a rural area of Yedashe Township, Myanmar. Biomass Bioenergy 2018, 109, 39-46. [CrossRef] 
68. Schmitt-Degenhardt, S. A Regional Perspective on Poverty in Myanmar; United Nations Development Program Myanmar: Yangon, Myanmar, 2013.

69. CIFOR Poverty Environment Network. The PEN Technical Guidelines-Version 4; Center for International Forestry Research: Bogor, Indonesia, 2007.

70. Hill, M.O. Diversity and evenness: A unifying notation and its consequences. Ecology 1973, 54, 427-432. [CrossRef]

71. Valdivia, C.; Dunn, E.G.; Jette, C. Diversification as a Risk Management Strategy in an Andean Agropastoral Community. Am. J. Agric. Econ. 1996, 78, 1329-1334. [CrossRef]

72. UNDP Myanmar. Accelerating Energy Access for All in Myanmar; United Nations Development Program Myanmar: Yangon, Myanmar, 2013; pp. 1-17.

73. IBM Corp. SPSS Statistics for Windows (Version 23.0); IBM Corp: Armonk, NY, USA, 2015.

74. Sovacool, B.K. Confronting energy poverty behind the bamboo curtain: A review of challenges and solutions for Myanmar (Burma). Energy Sustain. Dev. 2013, 17, 305-314. [CrossRef]

75. Khaine, I.; Woo, S.Y.; Kang, H. A study of the role of forest and forest-dependent community in Myanmar. Forest Sci. Technol. 2014, 10, 197-200. [CrossRef]

76. Hegde, R.; Enters, T. Forest products and household economy: A case study from Mudumalai Wildlife Sanctuary, Southern India. Environ. Conserv. 2000, 27, 250-259. [CrossRef]

77. Said, A.; O'Hara, P.; Tesfaye, A.; Abebe, B.; Mogessie, E. Participatory Forest Management Guidelines; NTFP-PFM Research \& Development Project South-West Forests \& Landscape Grouping (SWFLG); SWFLG: Masha, Ethiopia, 2013; pp. 1-35.

78. Bernard, A.; Gélinas, N. A Step Prior to REDD+ Implementation: A Socioeconomic Study. Int. J. For. Res. 2014, 2014, 1-10. [CrossRef]

79. He, J.; Dong, M.; Stark, M. Small mushrooms for big business? Gaps in the sustainable management of non-timber forest products in Southwest China. Sustainability 2014, 6, 6847-6861. [CrossRef]

80. Win, S. Investigation on Shifting Cultivation Practices Conducted by the Hill Tribes for the Development of Suitable Agroforestry Techniques in Myanmar. In Proceedings of the Annual Research Conference (Forestry Sciences), Yangon, Myanmar, 28-30 June 2005; pp. 28-96.

81. Belcher, B.; Schreckenberg, K. Commercialisation of Non-timber Forest Products: A Reality Check. Dev. Policy Rev. 2007, 25, 363. [CrossRef]

82. Neumann, R.P.; Hirsch, E. Commercialisation of Non-Timber Forest Products: Review and Analysis of Research; Center for International Forestry Research: Bogor, Indonesia, 2000; ISBN 979876451X.

83. Andersen, K.E. Institutional Models for a Future Recognition and Registration of Customary (Communal) Tenure in Myanmar. In Proceedings of the 2016 World Bank Conference on Land and Poverty, Washingdon DC, USA, 14-18 March 2016; pp. 1-24.

84. Ngendakumana, S.; Bachange, E.G.; Van Damme, P.; Speelman, S.; Foundjem-Tita, D.; Tchoundjeu, Z.; Kalinganire, A.; Bandiaky, S.B. Rethinking Rights and Interests of Local Communities in REDD+ Designs: Lessons Learnt from Current Forest Tenure Systems in Cameroon. ISRN For. 2013, 2013, 1-14. [CrossRef]

85. Springate-Baginski, O. Rethinking swidden cultivation in Myanmar: Policies for sustainable upland livelihoods and food security. In Shifting Cultivation Policies: Balancing Environmental and Social Sustainability; CABI: Oxfordshire, UK; Boston, MA, USA, 2017; pp. 226-241.

86. Mercycorps Myanmar. Myanmar Energy Poverty Survey. 2011. Available online: https://www.mercycorps. org/research-resources/myanmar-energy-poverty-survey (accessed on 2 May 2019).

87. Pode, R.; Pode, G.; Diouf, B. Solution to sustainable rural electrification in Myanmar. Renew. Sustain. Energy Rev. 2016, 59, 107-118. [CrossRef]

88. Myanmar Ministry of Environmental Conservation and Forestry. Myanmar's Intended Nationally Determined Contribution-INDC. 2015. Available online: https:/www4.unfccc.int/sites/ndcstaging/PublishedDocuments/ Myanmar\%20First/Myanmar\%27s\%20INDC.pdf (accessed on 2 May 2019).

89. Paumgarten, F.; Shackleton, C.M. Wealth differentiation in household use and trade in non-timber forest products in South Africa. Ecol. Econ. 2009, 68, 2950-2959. [CrossRef]

90. Sunderland, T.C.H.; Ndoye, O.; Harrison-Sanchez, S. Non-timber Forest Products and Conservation: What Prospects? In Non-Timber Forest Products in the Global Context; Shackleton, S., Shackleton, C., Shanley, P., Eds.; Springer: Heidelberg, Germany, 2011; pp. 209-224, ISBN 9783642179822. 
91. Barnes, D.F.; Krutilla, K.; Hyde, W. The Urban Household Energy Transition; Resources for the Future Press: Washington, DC, USA, 2005.

92. Alkan, H.; Korkmaz, M.; Tolunay, A. Assessment of primary factors causing positive or negative local perceptions on protected areas. J. Environ. Eng. Landsc. Manag. 2009, 17, 20-27. [CrossRef]

93. Jim, C.Y.; Xu, S.S.W. Stifled stakeholders and subdued participation: Interpreting local responses toward Shimentai nature reserve in South China. Environ. Manag. 2002, 30, 327-341. [CrossRef]

94. Kamaruddin, S.M.; Ahmad, P.; Alwee, N. Community Awareness on Environmental Management through Local Agenda 21 (LA21). Procedia Soc. Behav. Sci. 2016, 222, 729-737. [CrossRef]

95. Soe, K.T.; Yeo-Chang, Y. Perceptions of forest-dependent communities toward participation in forest conservation: A case study in Bago Yoma, South-Central Myanmar. For. Policy Econ. 2019, 100, 129-141. [CrossRef]

96. Bayrak, M.; Tu, T.; Marafa, L. Creating Social Safeguards for REDD+: Lessons Learned from Benefit Sharing Mechanisms in Vietnam. Land 2014, 3, 1037-1058. [CrossRef]

97. Lee, D.R.; Neves, B.; Wiebe, K.; Lipper, L.; Zurek, M. Rural Poverty and Natural Resources: Improving Access and Sustainable Management, ESA Working Paper No. 09-03; Agricultural Development Economics Division, The Food and Agriculture Organization of the United Nations: Rome, Italy, 2009.

98. Woollen, E.; Ryan, C.M.; Baumert, S.; Vollmer, F.; Grundy, I.; Fisher, J.; Fernando, J.; Luz, A.; Ribeiro, N.; Lisboa, S.N. Charcoal production in the mopane woodlands of Mozambique: What are the trade-offs with other ecosystem services? Philos. Trans. R. Soc. B Biol. Sci. 2016, 371, 20150315. [CrossRef]

(C) 2019 by the authors. Licensee MDPI, Basel, Switzerland. This article is an open access article distributed under the terms and conditions of the Creative Commons Attribution (CC BY) license (http://creativecommons.org/licenses/by/4.0/). 